\title{
Uniaxial tension of drying sieves
}

\author{
Nada V. Bojić ${ }^{1}$, Ružica R. Nikolićc ${ }^{2,3}$, Branimir Z. Jugovićc ${ }^{4}$, Zvonimir S. Jugović ${ }^{5}$, Milica M. Gvozdenović ${ }^{6}$ \\ ${ }^{1}$ Fabrika sita i ležaja "FASIL" A.D., Arilje, Serbia \\ ${ }^{2}$ Faculty of Engineering, Kragujevac, Serbia \\ ${ }^{3}$ Faculty of Civil Engineering, University of Žilina, Žilina, Slovakia \\ ${ }^{4}$ Institute of Technical Science Serbian Academy of Science and Arts, Belgrade, Serbia \\ ${ }^{5}$ Technical Faculty Čačak, University of Kragujevac, Čačak, Serbia \\ ${ }^{6}$ Faculty of Technology and Metallurgy, University of Belgrade, Belgrade, Serbia
}

\begin{abstract}
Although the literature contains numerous studies that have been developed to describe the nonlinear behavior of drying sieves operation, there are no papers that report deeper investigation of the drying sieve behavior when exposed to tension and thermo-stabilization. The aim of this paper is to provide insight into the elastoplastic behavior of the thermo-stabilized and non-stabilized sieves subjected to tensile force. Within this work both theoretical and experimental investigations were performed. The sieves were joined by using a spiral. In separate experiments, tests of wire base and weft of the weave mesh were performed, both for thermo-stabilized and non-thermo-stabilized sieves, sieves joining and the sieve thermo-stabilization itself. It was established that the thermo-stabilization of sieves provides for stability of sieves dimensions and that open thermo-stabilized drying sieve exhibits better mechanical properties and exploitation characteristics than the sieves joining.
\end{abstract}

Keywords: drying sieve, thermo-stabilization, joining spiral, tensile forces.

\section{SCIENTIFIC PAPER \\ UDC 676.8:676.015.8}

Hem. Ind. 67 (4) 655-662 (2013)

doi: 10.2298/HEMIND120824109B

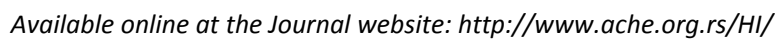

Drying sieves are widely applied in all groups of paper drying machines and they are used for the production of all kinds of paper and cardboard [1-4]. Since the operation of complete plants depends on proper operation of the drying sieves, special attention has been devoted to their reliable operation [5-8]. Exploitation of sieves leads to their elongation, wear, reduction in the wire cross-section and ultimately to breaking [9-15]. For this reason, joining of sieves is a very important process for ensuring their smooth exploitation. Drying sieves are exploited at a temperature of $120{ }^{\circ} \mathrm{C}$. The polyester that the sieves are made of is prone to contraction at elevated temperatures. In order for a sieve not to be exposed to shrinking forces, due to shrinkage at high temperatures in exploitation, a thermo-stabilization is performed at temperatures higher than the exploitation one [16-17]. Thanks to technical progress over time it became possible to influence certain properties of the material [18].

The main field of composite materials properties research are the tensile properties, where the indicators of the material behavior in tension are being determined, such as tensile strength, Poisson's ratio, deformations, etc. The objective of tensile testing of was not

Correspondence: B.Z. Jugović, Institute of Technical Science Serbian Academy of Science and Arts, Knez Mihailova 35, Belgrade, Serbia.

E-mail: branimir.jugovic@itn.sanu.ac.rs

Paper received: 24 August, 2012

Paper accepted: 19 November, 2012 only to determine the strength and deformation properties of the sieves material, but the tests performed had an objective to improve those properties of drying sieves as well, in order to obtain new fields for their application [19].

The closed (joined) sieve plays a role of a transporter (conveyer belt), which, while realizing the elastic connection also powers all the driven machine cylinders and as such is subjected to multifold straining of uneven intensity. As for the belt in operation of sieves exists the pre-loading in the stationary state $(\mathrm{S})$, loading of the "pulling" portion of the belt - sieve $\left(S_{1}\right)$ and loading of the "free" portion of the belt - sieve $\left(S_{2}\right)$, for which the following relations hold:

$$
\begin{aligned}
& S=K \frac{P}{2} \frac{e^{m \alpha}+1}{e^{m \alpha}-1}+\frac{W^{2}}{g} \\
& S_{1}=K P \frac{1}{e^{m \alpha}-1}+\frac{W^{2}}{g} \\
& S_{2}=K P \frac{e^{m \alpha}}{e^{m \alpha}}+\frac{W^{2}}{g}
\end{aligned}
$$

where $P(N)$ is the perimeter force which the sieve is transmitting, $K(\mathrm{~m})$ is the tolerance coefficient - in order to avoid the sieve's slipping it is always $K>1, \mathrm{~m}$ is the friction coefficient between the sieve and the cylinder, $\alpha,{ }^{\circ}$, is the enhancing angle of the sieve on the leading cylinder, $\gamma, \mathrm{kg} / \mathrm{m}$, is the sieve's weight per unit length, 
$v, \mathrm{~m} / \mathrm{s}$, is the sieve's rotational velocity and $g, \mathrm{~m} / \mathrm{s}^{2}$, is the gravity acceleration.

The sieve's stress due to folding over the cylinder can be expressed as:

$\sigma_{s}=E \frac{d_{0}}{D}$

where $E, \mathrm{~N} / \mathrm{m}^{2}$, is the Young's elasticity modulus and $D$, $\mathrm{m}$, is the cylinder diameter.

Due to loading during operation, the sieve elongation can be expressed as:

$\Delta L=\frac{S L}{E A}$

where: $\Delta L, \mathrm{~m}$, is the stretching (elongation) of the sieve, $S$ is the sieve load, $L, \mathrm{~m}$, is the base length, $E$, $\mathrm{N} / \mathrm{m}^{2}$, is the elasticity modulus, and $A, \mathrm{~m}^{2}$, is the base cross-sectional area.

The nominal length is always smaller than the base length, due to wear of the base wire the cross-sectional area is reduced, and thus the sieve elongation due to mechanical load is calculated according to the following equation:

$\Delta L_{m}=\frac{S^{\prime} L}{E^{\prime}}$

where $S^{\prime}$ is the stress per $1 \mathrm{~cm}$ of the drying sieve width, $L, \mathrm{~m}$, is the nominal length of the dry sieve, and $E^{\prime}, \mathrm{N} / \mathrm{m}^{2}$, is the elasticity modulus per $1 \mathrm{~cm}$ of the drying sieve width, which depends on degree of the sieve's wear.

Additionaly, the thermal elongation of the drying sieve is:

$$
\Delta L_{t}=\alpha \Delta t L
$$

where $\alpha, 1 /{ }^{\circ} \mathrm{C}$, is the linear thermal expansion coefficient and $\Delta t,{ }^{\circ} \mathrm{C}$, is the temperature increase.

The tensile strength of the non-thermo-stabilized sieve is calculated because the sieves that were not thermally stabilized have the worst mechanical properties:

$$
R_{\mathrm{m}}=\frac{F_{\text {break }}}{b d}
$$

where $R_{\mathrm{m}}, \mathrm{MPa}$, is the tensile strength, $F_{\text {break }}, \mathrm{N}$, is the breaking force, $d, \mathrm{~mm}$, is the drying sieve's sample thickness and $b, \mathrm{~mm}$, is the drying sieve's sample width.

The contribution of this paper represents an investigation of the drying sieve behavior, with and without temperature influence, and combined temperature and joining influence. Based on the appearance of the broken samples, micromechanical analysis of appearance and development of damages due to tensile loading was performed [20-26].

\section{EXPERIMENTAL}

The material the drying sieve is made of is a polyester wire (polybutylene terephthalate, PBT). In this work, a two weft sieve was used, with the base wire of rectangular cross-section of dimensions $0.36 \mathrm{~mm} \times 0.67$ $\mathrm{mm}$ and the weft wire of circular cross section with diameter of $1.6 \mathrm{~mm}$. The appearance of those wires is presented in Figures 1 and 2, respectively.

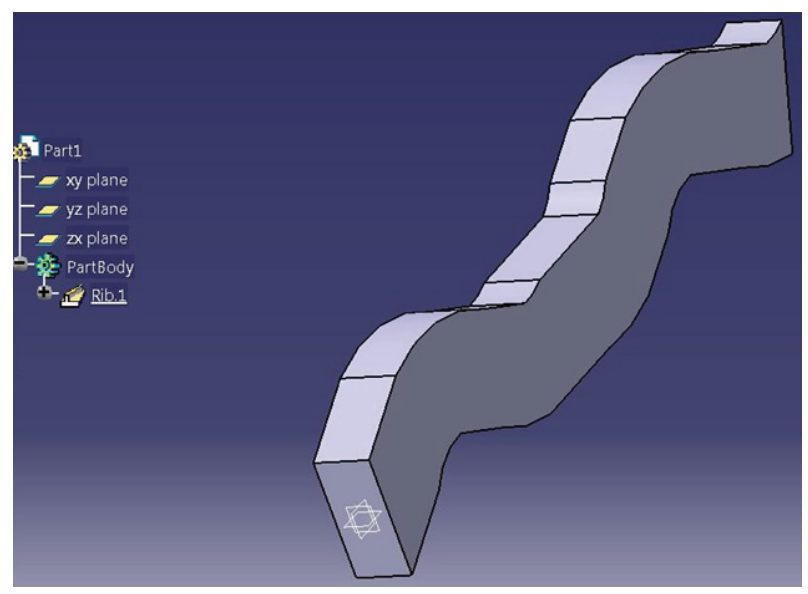

Figure1. Sieve base wire.

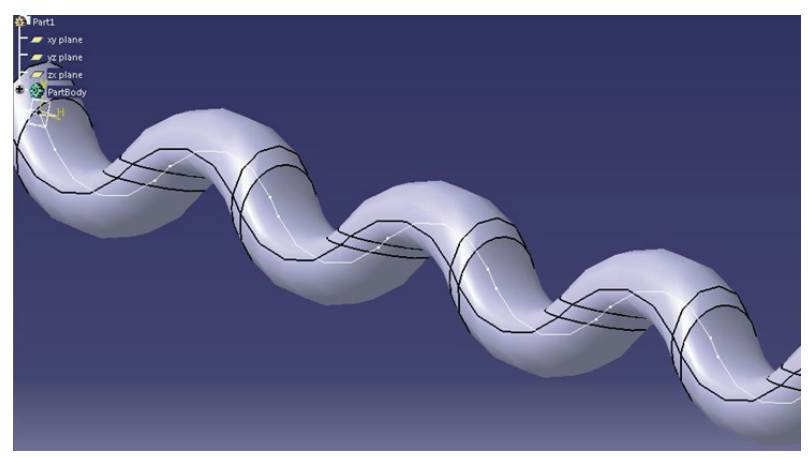

Figure 2. Sieve weft wire.

Prior to investigation, the specimen width and thickness (dry sieve) were controlled, with accuracy of $1 \%$. The static tensile test experiments were performed on testing machine ZWICK Roell Z010, Fmax $10000 \mathrm{~N}$; the maximum distance between the testing machine hydraulic jaws is $590 \mathrm{~mm}$. For the tensile tests, the maximum distance between the jaws was $200 \mathrm{~mm}$. The test speed was $400 \mathrm{~mm} / \mathrm{min}$. The limit force to stop the test was $60 \%$ of $F_{\max }$. The force upper limit is $500 \mathrm{~N}$. The length measure (standard path) was $50 \mathrm{~mm}$.

In the first part of the experiment the base wire elongation was investigated on 3 samples. The wire material base was polyester (PBT) of a rectangular cross section, $a_{0}=0.36 \mathrm{~mm}, b_{0}=0.67 \mathrm{~mm}$, the sample length was $L_{0}=200 \mathrm{~mm}$, the area weight was $80 \mathrm{~g} / \mathrm{m}^{2}$.

For the weft wire test, only one sample was used. The weft wire material is polyester (PBT). The weft wire 
was of a circular cross-section with diameter of 0.7 $\mathrm{mm}$, the sample length was $L_{0}=200 \mathrm{~mm}$.

Then the non-thermally stabilized (virgin) sieve and the thermally stabilized sieve were tested and their mechanical properties were determined. The material was polyester mesh (PBT). The sample dimensions were $a_{0}=1.6 \mathrm{~mm}$ and $b_{0}=20 \mathrm{~mm}$ and the length was $L_{0}=200 \mathrm{~mm}$.

Finally, the mechanical properties of the thermally stabilized open sieve were compared to properties of the sieve's joints. The joint itself was a woven unmarked one, where the thickness of the joining spiral was approximately equal to the thickness of the sieve (the experimental procedure was the same as described in the previous section).

The joining of the sieves was performed in the following way:

The wefts were were pulled out from the sieve for about 10 to $15 \mathrm{~cm}$, leaving the bases free. Then, one end was clamped between the two sieves clamp, where the free ends were ripped. The strip was then prepared from which the base was pulled out and the weft remained, about 10 to $15 \mathrm{~cm}$ wide. Every single weft was threaded through the joining device, to realize the weaving as in the real sieve. Then the joining spiral was prepared. The size of the spiral depends on the sieve's thickness and on the weaving. The ripped wires were then, one after another, bent over the spiral and weft into the ripped weft wires; the same procedure was applied at the other end of the sieve, where the spiral was weft. Afterwards, the two ends were joined into an endless strip in the way that the two spirals are zipped together. A wire was pulled through the holes to perform the joining. After this, the neutral ends of the base were cut off, and the tips were treated by special sandpaper, in order to obtain a fine surface of the sieve. Then, the second thermal stabilizing was performed in order to fasten the joint. The edges of the sieve were finally processed by let-lamp, i.e., they are molten together and a polyurethane two-component glue, which is stable at elevated temperatures, was applied as an about $40 \mathrm{~mm}$ wide layer.

\section{RESULTS AND DISCUSSION}

\section{Uniaxial tensile test of a virgin base wire from the coil}

The test of the base wire elongation is shown in Figure 3, while the results of the test are shown in Tables 1 and 2.

Table 1. Results of the virgin base wire tension test $\left(F_{\text {break }}-\right.$ breaking force, $\varepsilon_{\text {break }}$ - extension at break)

\begin{tabular}{lcc}
\hline Sample no. & $F_{\text {break }} / N$ & $\varepsilon_{\text {break }} / \%$ \\
\hline 1 & 114.47 & 33.89 \\
2 & 107.42 & 29.76 \\
3 & 111.96 & 32.20 \\
\hline
\end{tabular}

Table 2. The virgin base wire test statistics $\left(F_{\text {break }}-\right.$ breaking force, $\varepsilon_{\text {break }}$ - extension at break, $x_{s r}$ - arithmetic mean of measurements, $\sigma_{x}$-quadratic mean of measurements, $\delta x-$ relative error of measurements)

\begin{tabular}{lcc}
\hline Parameter & $F_{\text {break }} / \mathrm{N}$ & $\varepsilon_{\text {break }} / \%$ \\
\hline$x_{\text {sr }}$ & 111.28 & 31.95 \\
$\sigma_{x}$ & 3.57 & 2.08 \\
$\delta x / \%$ & 3.21 & 6.50 \\
\hline
\end{tabular}

Zwick Roell software was used to obtain values of $F_{\text {break }}$ and $\varepsilon_{\text {break }}$ and perform statistical analysis of the results. Tests of the three base wire samples showed that wires of rectangular cross-section have a slight initial elongation of $2 \%$ at the force of $28 \mathrm{~N}$, because the force did not reach the value prescribed by the manufacturer. The further force increase up to $106 \mathrm{~N}$

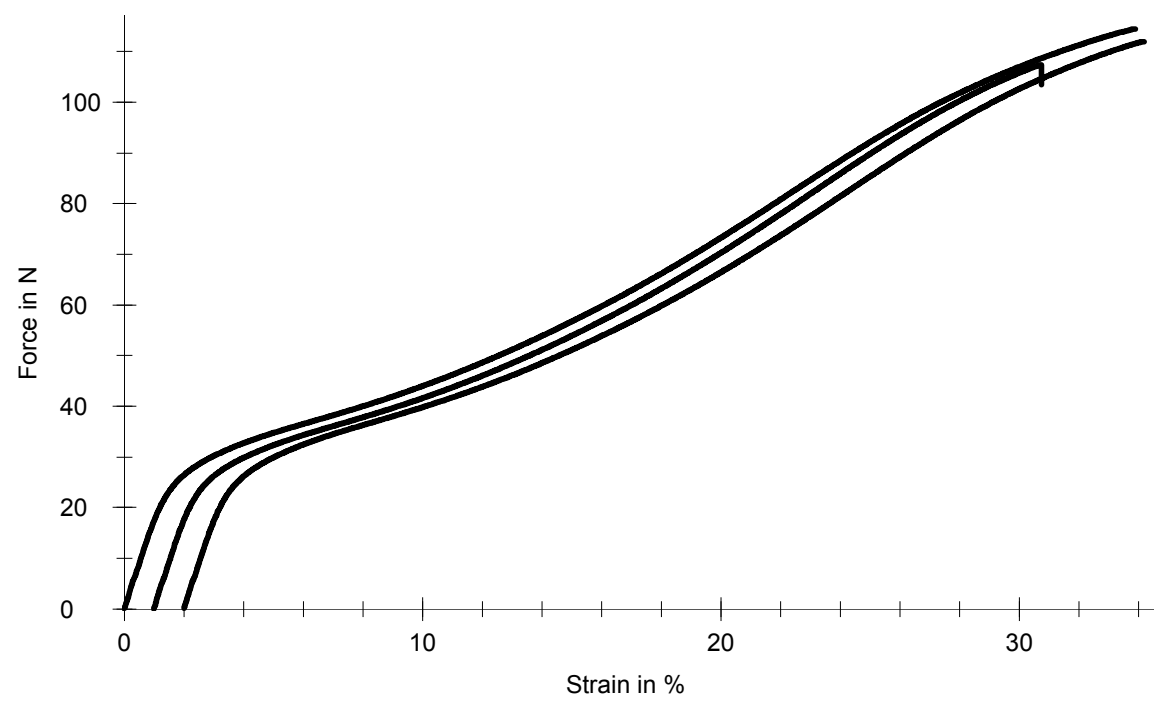

Figure 3. Force-strain diagram for tension test of the virgin base wire. 
caused maximum elongation of the wire, though it was not equal for all the three samples. The reason for this difference lies in fact that the wire was not thermally stabilized and the cross section is approximated as rectangular. The maximum breaking force, obtained by static calculation, for all the three samples was 455.91 $\mathrm{N}$ and the corresponding elongation was $31.95 \%$. Comparison of mechanical properties of the base and weft wires (of the rectangular and circular cross-sections, respectively) can be seen that the base wire elongation is higher for about 3 to $8 \%$, which is in accordance with the way the sieves are manufactured. The weft wire deformation arises due to forces of the base wires; the weft wire shrinks during the sieve's extension, while the base wire is elongated, both as a function of the tensile force per unit area $\left(\mathrm{cm}^{2}\right)$.

\section{Uniaxial tensile test of a virgin weft wire from the coil}

In uniaxial tension of the weft wire, as the test progresses, the increment of wire length elongation becomes larger for the same increment of force, thus the curve bends towards the abscissa axis. The linear force-extension dependence (Figure 4), which is normal for metals, here practically does not exist, i.e., the deformation is plastic, almost from the very beginning of the test. The property of the wire to significantly deform plastically, without breaking, is the most useful property in sieves manufacturing. Within the force interval 0 to $45 \mathrm{~N}$ the small elongation of the wire occurs, and the force-deformation curve is exponential function. In the next interval, 45 to $169 \mathrm{~N}$, the wire is maximally extended; where in the narrow range of 23 to $24 \%$ of elongation, the more prominent change of the curve slope occurs as well as the bend towards the abscissa. With further increase of force, the ability of material to deform further is exhausted and the breaking of the wire occurs at the maximum tensile force of
$426.89 \mathrm{~N}$, with the maximum achieved elongation of $24.68 \%$

\section{Uniaxial tensile test of a virgin thermally non- stabilized sieve}

The obtained force deformation diagram is shown in Figure 5, while the results of the test are shown in Tables 3-5.

As can be seen from Table 6, the tensile strength of the sieve exhibits small dispersion around the average value of $R_{\mathrm{m}, \mathrm{av}}=641.2 \mathrm{MPa}$. This is explained by the manufacturing technology of manually weaving threading the sieve on the weaving machine. To get the real picture about the virgin non thermo-stabilized sieve, a micromechanical analysis was performed, which showed that this sieve's wires were exposed to bending stress.

\section{Uniaxial tensile test of a virgin thermally stabilized sieve}

The obtained force deformation diagram is shown in Figure 6, while the results of the test are shown in Tables 6 and 7.

Since the non-thermo-stabilized sieves are obtained by weaving the base and weft wires, which do not have the same mechanical properties, thermal stabilization of the sieve was performed. This results in the two kinds of wires having the same mechanical properties, so that they can be compared to each other.

Thermal stabilization was performed by exposing the sieve to elevated temperatures, gradually, in several passes. The temperature was increased in each pass for $10^{\circ} \mathrm{C}$, until the final temperature was reached. The sieve was kept at that temperature for 15 min. During the entire heating process, the sieve was subjected to tensile forces in both directions (base and weft wires) and the sieve was moved through the machine at a constant speed of $2 \mathrm{~m} / \mathrm{min}$. The pulling force was pre-

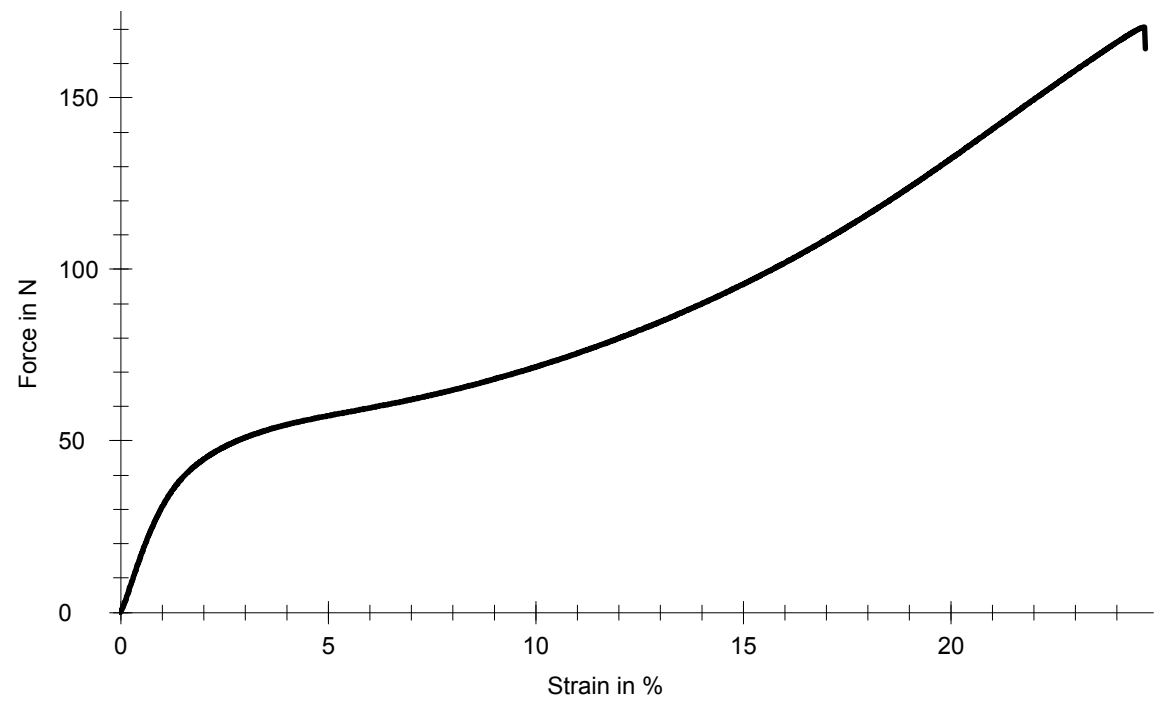

Figure 4. Force-strain diagram for tension test of the weft wire. 


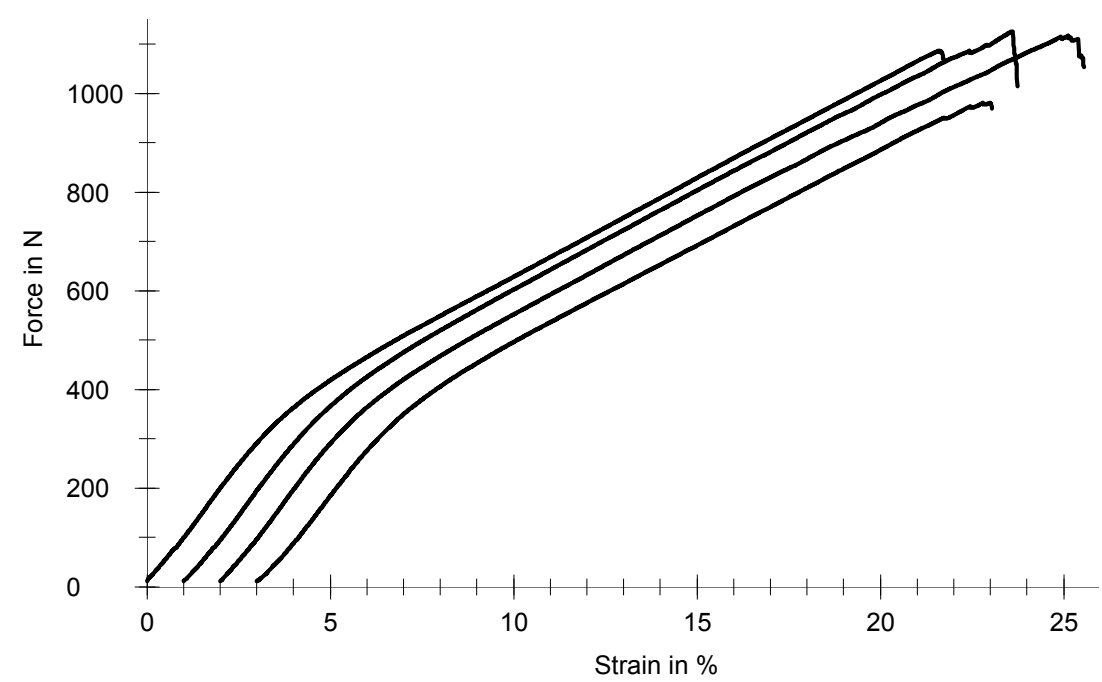

Figure 5. Force-strain diagram of the non thermo-stabilized sieve.

scribed for each type of wire forming the sieve. The sieve is considered as thermally stable if no cracks appear on it after the described process. A thermally stabilized sieve shrinks with respect to a non-stabilized sieve such that the decrease in width is less than decrease in its length, which actually is the objective of thermal stabilization - for the sieve to become homogeneous.

Table 3. Results of the not thermo-stabilized sieve tension test ( $F_{\text {break }}$ - breaking force, $\varepsilon_{\text {break }}$ - extension at break)

\begin{tabular}{lcc}
\hline Sample No. & $F_{\text {break }} / N$ & $\varepsilon_{\text {break }} / \%$ \\
\hline 1 & 1068.68 & 21.72 \\
2 & 1013.73 & 22.73 \\
4 & 1052.62 & 23.55 \\
5 & 968.39 & 20.05 \\
\hline
\end{tabular}

By comparing the mechanical properties of the two sieves, non-thermo-stabilized and thermo-stabilized, one could conclude that the former sieve has worse mechanical properties; its elongation average value at break was $\varepsilon_{\text {break }}=22.01 \%$, while for the latter sieve, this value was $\varepsilon_{\text {break }}=225.50 \%$. The obtained experimental results support this conclusion.

Table 4. The non-thermo-stabilized sieve tension test statistics ( $F_{\text {break }}-$ breaking force, $\varepsilon_{\text {break }}-$ extension at break $\%, x_{s r}-$ arithmetic mean of measurements, $\sigma_{x}$ - quadratic mean of measurements, $\delta x$ - relative error of measurements)

\begin{tabular}{lcc}
\hline Parameter & $F_{\text {break }} / \mathrm{N}$ & $\varepsilon_{\text {break }} / \%$ \\
\hline$x_{\text {sr }}$ & 1025.86 & 22.01 \\
$\sigma_{x}$ & 44.72 & 1.51 \\
$\delta x / \%$ & 4.36 & 6.86 \\
\hline
\end{tabular}

Table 5. The tensile strength of non-thermo-stabilized sieve

\begin{tabular}{lcccc}
\hline Sample No. & 1 & 2 & 3 & 4 \\
\hline$R_{\mathrm{m}} / \mathrm{MPa}$ & 667.9 & 633.58 & 657.88 & 605.24 \\
\hline
\end{tabular}

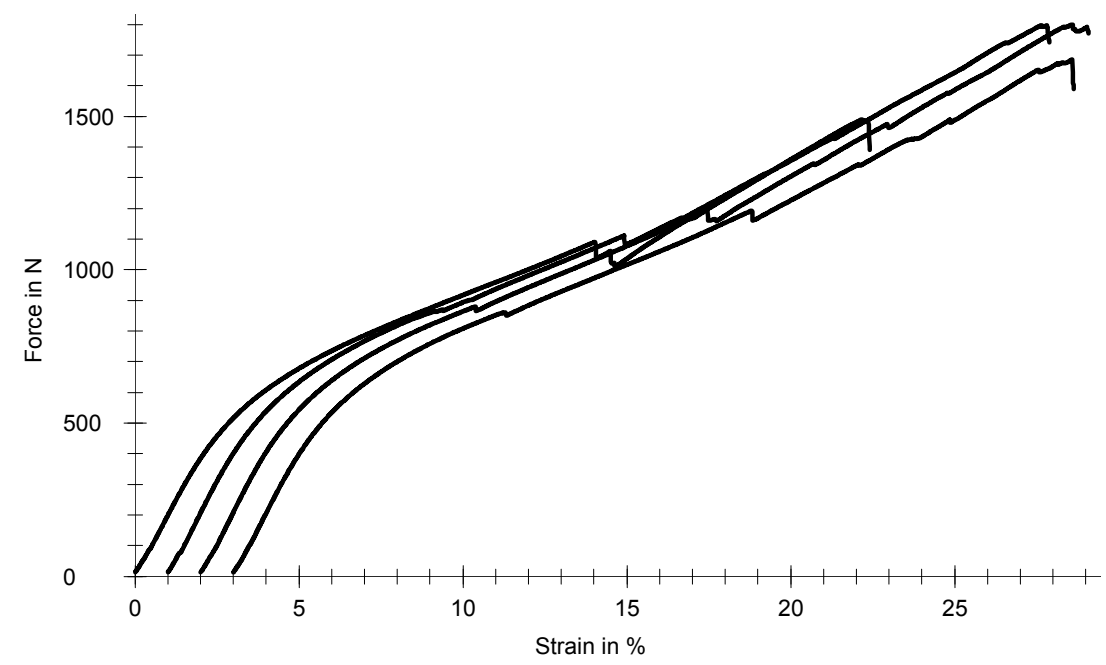

Figure 6. Force-strain diagram of the thermo-stabilized sieve. 
Table 6. Results of thermo-stabilized sieve tension test $\left(F_{\text {break }}\right.$ breaking force, $\varepsilon_{\text {break }}-$ extension at break, $\sigma_{\text {break }}-$ tension at break)

\begin{tabular}{lccc}
\hline Sample No. & $F_{\text {break }} / \mathrm{N}$ & $\sigma_{\text {break }} / \mathrm{N} \mathrm{mm}^{-2}$ & $\varepsilon_{\text {break }} / \%$ \\
\hline 1 & 1490.70 & 43.42 & 22.40 \\
2 & 1797.32 & 54.45 & 26.88 \\
3 & 1800.66 & 55.29 & 27.08 \\
4 & 1685.29 & 49.64 & 25.64 \\
\hline
\end{tabular}

Table 7. The thermo-stabilized sieve tension test statistics $\left(F_{\text {break }}\right.$ - breaking force, $\varepsilon_{\text {break }}-$ extension at break, $\sigma_{\text {break }}-$ tension at break)

\begin{tabular}{lccc}
\hline Parameter & $F_{\text {break }} / \mathrm{N}$ & $\sigma_{\text {break }} / \mathrm{N} \mathrm{mm}^{-2}$ & $\varepsilon_{\text {break }} / \%$ \\
\hline$x_{\mathrm{sr}}$ & 1693.49 & 50.70 & 25.50 \\
$\sigma_{x}$ & 145.44 & 5.46 & 2.16 \\
$\delta x / \%$ & 8.59 & 10.76 & 8.48 \\
\hline
\end{tabular}

\section{Uniaxial tensile test of the thermally stabilized sieve's joint}

The obtained force deformation diagram is shown in Figure 7, while the results of the test are shown in Tables 8 and 9.

Table 8. Results of tension test of the thermally stabilized sieve's joint ( $F_{\text {break }}-$ breaking force, $\varepsilon_{\text {break }}-$ extension at break, $\sigma_{\text {break }}$ - tension at break)

\begin{tabular}{lccc}
\hline Sample No. & $F_{\text {break }} / \mathrm{N}$ & $\sigma_{\text {break }} / \mathrm{N} \mathrm{mm}^{-2}$ & $\varepsilon_{\text {break }} / \%$ \\
\hline 1 & 1191.64 & 37.01 & 20.37 \\
2 & 871.56 & 13.02 & 11.43 \\
3 & 1125.28 & 34.99 & 19.38 \\
4 & 1125.59 & 33.17 & 21.84 \\
\hline
\end{tabular}

The closed (welded or soldered) sieve plays the role of the belt transmitter, which, by realizing the elastic connection and transmitting the power, drives all the cylinders of the machine and thus it is exposed to multifold loading of uneven intensity. As with the belt in operation, here also exists the pre loading in the stationary state, loading of the pulling portion of the belt-sieve and loading of the led ("free") portion of the belt-sieve. For these reasons, the sieve is first thermally stabilized and then joined. From the results of tensile tests of all the sieves, one can see that the joined sieve had a carrying capacity (average breaking force) of $29.55 \mathrm{~N} / \mathrm{mm}^{2}$, which is 1.7 times lower than the average breaking force of the thermally stabilized sieve, which was $50.70 \mathrm{~N} / \mathrm{mm}^{2}$. The thermally stabilized sieve's joint is the weakest point, with respect to the thermally stabilized sieve itself. It was noticed that in tensile tests the joined sieve was breaking either in the immediate vicinity of the joining spiral or at the spiral. Due to the uneven stress distribution the exterior ("surface") threads are being pulled out from the sample first and it breaks at the angle of $45^{\circ}$, which is caused by appearance of shear stresses. In further extension of the sample, the neighboring threads break, and the crack that appeared due to breaking of the external threads propagates through the middle threads and causes appearance of a macro-crack, i.e., the breaking of the whole sample. Software Zwik Roell moves the notch for each new sample (curves in Figures 3 to 7).

Table 9. Tension test of the thermally stabilized sieve's joint statistics ( $F_{\text {break }}$ - breaking force, $\varepsilon_{\text {break }}-$ extension at break, $\sigma_{\text {break }}-$ tension at break)

\begin{tabular}{lccc}
\hline Parameter & $F_{\text {break }} / \mathrm{N}$ & $\sigma_{\text {break }} / \mathrm{N} \mathrm{mm}^{-2}$ & $\varepsilon_{\text {break }} / \%$ \\
\hline$x_{\mathrm{sr}}$ & 1078.52 & 29.55 & 18.26 \\
$\sigma_{x}$ & 141.46 & 11.13 & 4.66 \\
$\delta x / \%$ & 13.12 & 37.67 & 25.52 \\
\hline
\end{tabular}

\section{CONCLUSION}

Proper operation of drying sieves affects the work of complete plants, therefore special attention should

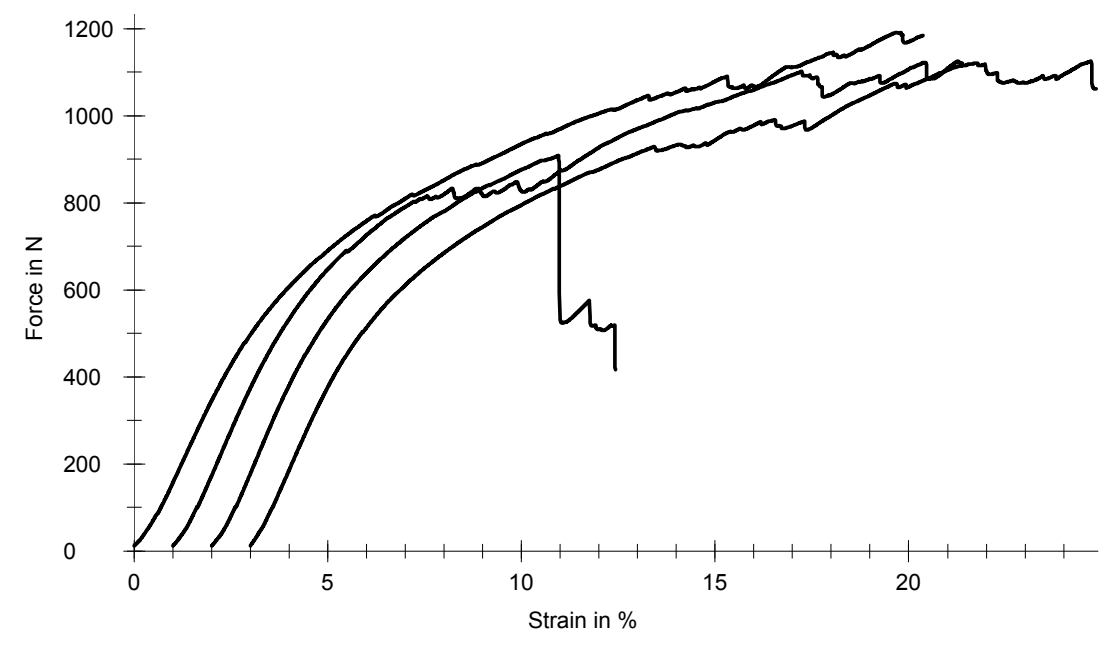

Figure 7. Force-strain diagram of the thermally stabilized sieve's joint. 
be paid to their reliable operation. Exploitation of the sieves results in their elongation, wear, reduction in cross-section of wire and ultimately breaking. The objective is to produce a drying sieve with low air flow and high resistance to soiling.

The sieve joint is the weakest point of the sieve and its mechanical properties should not be below $30 \%$ of mechanical properties of the sieve itself. Anything below that is not considered a good joint. Due to the load during operation the sieves are elongated. Stresses are the highest for sieves that operate on rollers of the smallest diameter. Wear of the base wires causes increase of the sieve stress. Additional sieve elongation is caused by increased operating temperature, which causes shrinkage of materials. To avoid this shrinkage, thermal stabilization of the sieves is performed, thus the stability of the sieve's dimensions is ensured, as well as its homogeneity. Another reason for thermal stabilizing is that it strengthens molecular bonds in the polymer, thus securing sieve strength. Based on the performed experiments, all the aforementioned conclusions were confirmed, since the best mechanical properties were obtained for the thermally stabilized sieve, while the worst properties were obtained for the non-stabilized one. The mechanical properties of thermally stabilized sieves are better because they can withstand a higher force before the sieve breaks.

\section{Acknowledgement}

Parts of this research were supported by the Ministry of Education, Science and Technological Development of Republic of Serbia through Grants ON174004, "Micromechanics criteria of damage and fracture", and TR 32036, "Development of software for solving the coupled multi-physical problems", and realized while Mrs. Ružica R. Nikolić was on the SAIA grant of the Slovak Republic government at University of Žilina, Slovakia.

\section{REFERENCES}

[1] A. Golubović, Tehnologija izrade i svojstva papira, Grafički fakultet, Zagreb, 1984 (in Croatian).

[2] F. Ćorlukić, Tehnologija papira, Školska knjiga, Zagreb, 1987(in Croatian).

[3] M. Križan, Savremena proizvodnja papira, Mrlješ, Beograd, 1997(in Serbian).

[4] W. Kufferath, Plastic sieves for dehydration of paper, Das Papier, 1972.

[5] H.G. Merkus, Sieves and Sieving, Particle Size Measurements, in: Particle Size Measurements: Fundamentals, Practice, Quality, Springer, 2009, pp. 219-240.

[6] M. Krgovic, Determining parameters for a rate of heat transmission during paper drying, Cell. Chem. Technol. 38 (2004) 277-287.
[7] M.V. Krgović, V.J. Valent, M.M. Kršikapa, M.B. Milojević, B.S. Rašeta, D.V. Ošap, Increasing of energy efficiency in paper industry, Hem. Ind. 62 (2008) 233-246.

[8] J. Schlegel, Erfahrungen von verchiedenen Schuhpressen-Anwendungen, Wochenbl. Papierfabr. 136 (2008) 670-680.

[9] WS. Chow, Tensile and thermal properties of poly-butyleneterephtalate)/organo-montmorillonite nano composites, Malays. Polym. J. 3 (2008) 1-13.

[10] R. Srinivasan, K. Young, N. Ricci, J. Sawka, Engineering polymers in non-wovens, fibers and other extruded substrates - processing and applications for polyphenylene sulfide and thermoplastic polyesters, INTC TAPPI, 2001.

[11] S. Hashemi, Temperature dependence of work of fracture parameters in polybutylene-terephthalate (PBT), Pol. Eng. Sci. 40 (2000) 1435-1446.

[12] A. Pegoretti, A. Gorigato, A. Penati, Tensile mechanical response of polyethylene-clay nano composites, Express Polym. Lett. 1 (2007) 123-132.

[13] I.M. Ward, An introduction to the mechanical properties of solid polymers, John Wiley and sons, Chichester, 1993.

[14] S. Qin, J. Yu, Q. Zheng, M. He, H. Zhu, Morphology and mechanical properties of nylon 6/PBT blends compatibilized with styrene/maleic anhydride copolymer, Chem. Res. Chinese U. 23 (2007) 726-732.

[15] Z.A. Mohd Ishak, Y. W. Leong, M. Steeg, J. Karger-Kocsis, Mechanical properties of woven glass fabric reinforced in situ polymerized poly-butylene terephthalate) composites, Mater. Sci. 67 (2007) 390-399.

[16] D.F. Wu, C.X. Zhou, X. Fan, D.L. Mao, Z. Bian, Linear rheological behavior and thermal stability of poly(butylene terephthalate)/epoxy/clay ternary nano composites, Polym. Degrad. Stab. 87 (2005) 511-520.

[17] D.R. Kelsey, K.S. Kiibler, N. Tutunjian, Thermal stability of poly(trimethylene terephthalate), Polymer 46 (2005) 8937-8947.

[18] M.Krgović, O. Perviz, Grafički materijali, Tehnološkometalurški fakultet, Beograd, 2005 (in Serbian).

[19] N. Bojić, Z. Jugović, R. Nikolić, V. Lazić, R. Čukić, Determination of optimal way for the diagonal sieves joining, IRMES, Zlatibor, Serbia, 2011.

[20] J. Wu, Y.W. Mai, B. Cotterell, Fracture toughness and fracture mechanisms of PBT/PC/IM blend Part I - Fracture properties, J. Mater. Sci. 28 (1993) 3373-3384.

[21] S. Hashemi, Determination of the fracture toughness of polybutylene terephthalate (PBT) film by the essential work method: Effect of specimen size and geometry, Pol. Eng. Sci. 40 (2000) 798-809.

[22] S. Hashemi, Temperature dependence of work of fracture parameters in polybutylene terephthalate (PBT), Pol. Eng. Sci. 40 (2000) 1435-1447.

[23] P. Du, B. Xue, Y. Song, S. Lu, J. Yu, Q. Zheng, Fracture surface characteristics and impact properties of poly(butylene terephthalate), Polym. Bull. 64 (2012) 185$-196$.

[24] W. Grellmann, S. Seidler, Deformation and fracture behavior of polymers, Springer, 2001. 
[25] W. Grellmann, S. Seidler, K Jung, K. Kotter, Crack resistance behavior of polypropylene copolymers, J. Appl. Polym. Sci. 64 (2001) 1079-1091.
[26] A. Pavan, Fracture of polymers, composites and adhesives II, Elsevier, Ampsterdam, 2003.

\section{IZVOD}

\section{JEDNOOSNO ZATEZANJE SUŠNIH SITA}

Nada V. Bojić ${ }^{1}$, Ružica R. Nikolić ${ }^{2,3}$, Branimir Z. Jugović ${ }^{4}$, Zvonimir S. Jugović ${ }^{5}$, Milica M. Gvozdenović ${ }^{6}$

${ }^{1}$ Fabrika sita i ležaja "FASIL" A.D., Arilje, Srbija

${ }^{2}$ Fakultet inženjerskih nauka, Univerzitet u Kragujevcu, Kragujevac, Srbija

${ }^{3}$ Faculty of Civil Engineering, University of Žilina, Žilina, Slovakia

${ }^{4}$ Institut tehničkih nauka Srpske akademije nauka i umetnosti, Beograd, Srbija

${ }^{5}$ Tehnički fakultet Čačak, Univerzitet u Kragujevcu, Čačak, Srbija

${ }^{6}$ Tehnološko-metalurški fakultet, Univerzitet u Beogradu, Beograd, Srbija

\section{(Naučni rad)}

lako literatura sadrži brojne studije koje su razvijene da bi opisale nelinearna ponašanja sušnih sita, radovi iz ove oblasti nisu dublje istražili ponašanje sušnih sita pri zatezanju i termostabilizaciji. Cilj ovog rada je da pruži uvid u elastoplastično ponašanje termostabilizovanih i netermostabilizovanih sita pod dejstvom sile zatezanja. U okviru ovog rada izvršena su teorijska i eksperimentalna ispitivanja. Spajanje sita je izvršeno pomoću spirale. U odvojenim eksperimentima je radjeno ispitivanje žica osnove i potke od kojih se tkaju sita, netermostabilizovana sita, termostabilizovana sita, spojevi sita, kao i eksperiment termostabilizacije sita. Ispitivanjem se došlo do zaključka da termostabilizovana sita obezbeđuju stabilnost dužine i širine sita, kao i da otvoreno termostabilizovano sušno sito ima bolje mehaničke osobine i eksploatacione karakterisike nego spoj sita.

Ključne reči: Sušna sita • Spoj spiralom • Termostabilizacija 